Vol. 24, No. 2, April 2021, hlm. 331-341

p-ISSN: 1410-9344; e-ISSN: 2549-5631

\title{
Penerapan Mesin Pemarut Singkong untuk Meningkatkan Produktivitas Usaha Makanan Tradisional “Gebleg” di Kota Magelang
}

\author{
${ }^{1}$ Rany Puspita Dewi, ${ }^{2}$ Sri Hastuti, ${ }^{3}$ Herru Santosa Budiono \\ ${ }^{123}$ Jurusan Teknik Mesin, Fakultas Teknik, Universitas Tidar \\ Email: ${ }^{1}$ ranypuspita@untidar.ac.id, ${ }^{2 h}$ hastutisrimesin@untidar.ac.id, ${ }^{3}$ herru.santosa@yahoo.co.id
}

\section{Article Info}

Submitted: 19 November 2020

Revised: 27 Februari 2021

Accepted: 13 Maret 2021

Published: 21 April 2021

Keywords: Cassava grater machine, Traditional food, Productivity, Magelang

Kata kunci: Mesin pemarut singkong, Makanan tradisional, Produktivitas, Magelang

\begin{abstract}
Meteseh Jayengan is located in Magelang Tengah District, Magelang City, which is located about $3.5 \mathrm{~km}$ from downtown Magelang. Most of the residents of Meteseh Jayengan village, Magelang sub-district have traditional food production businesses. Most of the traditional snacks production process is still done machineless, so it is ineffective. The aim of the Community Partnership Program (PKM) activity is to increase the production capacity of traditional food "gebleg", one of them is Mrs. Murdinah's business. Activity of PKM in Meteseh Jayengan, Magelang Urban Village is carried out in two stages. The early stage is done by conducting field surveys to obtain documentation data and followed by discussions with Mrs. Murdinah as stakeholder. The second stage is the stage of developing a solution by applying appropriate technology that is cassava grater machine. The result of the PKM activity is a cassava grater machine which has capacity of $30 \mathrm{~kg} /$ day with a power of 20 watts. Through the application of the cassava grater machine, it can increase the production capacity from $15 \mathrm{~kg} /$ day to $30 \mathrm{~kg} /$ day. The standard of living of the people of Meteseh Jayengan, Magelang Village has also increased with an increase in income of up to $100 \%$.
\end{abstract}

Abstrak
Kampung Meteseh Jayengan terletak di Kecamatan Magelang
Tengah Kota Magelang, yang berlokasi sekitar 3,5 Km dari pusat
kota Magelang. Sebagian besar warga masyarakat kampung Meteseh
Jayengan, Kelurahan Magelang memiliki usaha produksi makanan
tradisional. Sebagian besar proses produksi jajanan tradisional
masih dilakukan tanpa mesin, sehingga tidak efektif secara waktu.
Tujuan kegiatan Program Kemitraan Masyarakat (PKM) yaitu untuk
meningkatkan kapasitas produksi makanan tradisonal "gebleg", salah
satunya usaha milik Bu Murdinah. Kegiatan PKM di Meteseh Jayengan,
Kelurahan Magelang dilaksanakan dalam dua tahap. Tahap awal adalah
observasi dengan melakukan survei lapangan untuk memperoleh data
dokumentasi dan dilanjutkan diskusi dengan Bu Murdinah sebagai


stakeholder. Tahap kedua adalah tahap pengembangan solusi melalui penerapan teknologi tepat guna yaitu mesin pemarut singkong. Hasil kegiatan PKM adalah berupa mesin pemarut singkong yang memiliki kapasitas $30 \mathrm{~kg} /$ hari dengan daya 20 watt. Melalui penerapan mesin pemarut singkong yang dibuat dapat meningkatkan kapasitas produksi yang semula hanya $15 \mathrm{~kg} /$ hari menjadi $30 \mathrm{~kg} /$ hari. Taraf hidup masyarakat Meteseh Jayengan, Kelurahan Magelang juga meningkat dengan meningkatnya pendapatan hingga 100\%.

\section{PENDAHULUAN}

Sebagian besar warga masyarakat Kampung Meteseh Jayengan, Kelurahan Magelang memiliki usaha produksi jajanan tradisional sebagai pemenuhan kebutuhan ekonomi sehari-hari. Salah satunya adalah Bu Murdinah yang selama kurang lebih 10 tahun memproduksi makanan tradisional "gebleg". Gebleg adalah makanan tradisional yang berbentuk bulat berwarna putih bersih dan diolah dengan cara digoreng.

Usaha jajanan tradisional $\mathrm{Bu}$ Murdinah memiliki kapasitas produksi sekitar $15 \mathrm{~kg} /$ hari. Jajanan tradisional "gebleg" yang diproduksi biasanya dipasarkan ke sekitar wilayah kota Magelang. Harga jual dari jajanan tradisional "gebleg" adalah sekitar Rp. 800/buah. Harga ini cukup terjangkau bagi kalangan masyarakat. Hampir seluruh proses produksi jajanan "gebleg" masih dilakukan secara manual mulai dari persiapan bahan baku, pemarutan bahan baku, pengukusan bahan baku, pencampuran bahan baku, dan pencetakan adonan. Oleh karena itu, tim mencoba memberikan alternatif solusi melalui pembuatan mesin pemarut singkong skala kecil bagi mitra. Hal ini dikarenakan mesin pemarut yang tersedia di pasaran berskala besar dengan banyak instrumen, sehingga kurang cocok untuk skala kecil dengan pemeliharaan yang rumit (Alfons, Argo, dan Lutfi 2015).

Proses pemarutan merupakan salah satu bentuk dari operasi pemotongan (cutting) yang memerlukan sejumlah energi (Aman et al., 2019). Pemarutan merupakan proses pengecilan ukuran yang digunakan untuk pengolahan ubi kayu (Andasuryani et al., 2019). Kapasitas pemarutan merupakan kemampuan mesin dalam memarut per satuan waktu (Reniana, Darma, dan Kurniawan 2020). Beberapa faktor yang mempengaruhi proses pemarutan adalah sifat mekanis bahan, geometri, dan bentuk tepi pemotong. Proses produksi jajanan tradisional "gebleg" terdiri dari beberapa tahap (Gambar 1) yaitu;

a. Persiapan bahan baku pembuatan gebleg yang terdiri dari singkong, tepung kanji, bawang putih, dan garam.

b. Pengupasan singkong dan pencucian singkong.

c. Pemarutan singkong dengan menggunakan parutan manual (terbuat dari kayu), yang memerlukan waktu sekitar 1,5 jam untuk setiap bahan baku $15 \mathrm{~kg}$ singkong.

d. Pengukusan parutan singkong kurang lebih selama 30 menit.

e. Pemerasan parutan singkong dengan menggunakan kain untuk mengambil saripati singkong.

f. Pencampuran parutan singkong yang telah dikukus (masih dalam kondisi panas) dengan tepung kanji (kering), bawang, dan garam hingga campuran menjadi lebih kalis.

g. Menguleni adonan "gebleg" hingga adonan menjadi kalis.

h. Pembentukan adonan "gebleg" menjadi bentuk bulat-bulat.

i. Penggorengan adonan "gebleg".

Proses pemarutan singkong masih dilakukan secara manual menggunakan parutan konvensional dari kayu dan memerlukan waktu kurang lebih 1,5 jam. Selain membutuhkan waktu yang cukup lama, hasil parutan singkong yang diperoleh juga sangat terbatas. Mesin pemarut adalah alat yang digunakan untuk mempermudah proses pemarutan dengan penggerak berasal dari tenaga motor (Siswanto, 2018). Untuk meningkatkan kapasitas produksi maka diperlukan mesin bertenaga motor (Aman et al., 2019). Mesin bertenaga motor dapat meningkatkan efisiensi kerja pada proses pemarutan dan pemerasan (Ishak, Djamalu, 
dan Akuba 2016). Besarnya tenaga motor yang digunakan dalam mesin pemarut disesuaikan dengan kapasitas produksi yang diinginkan dan

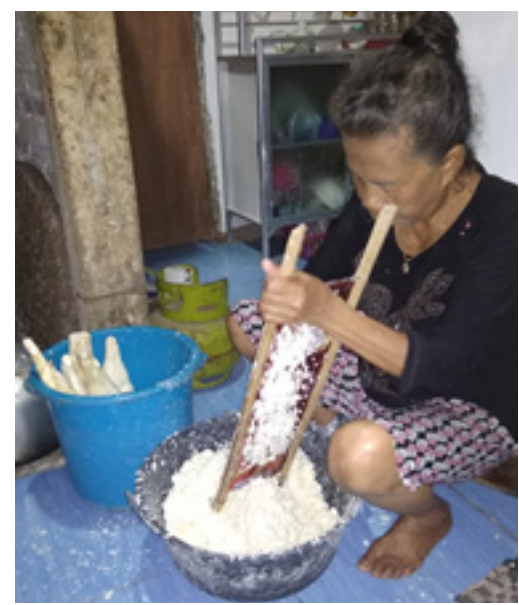

(a)

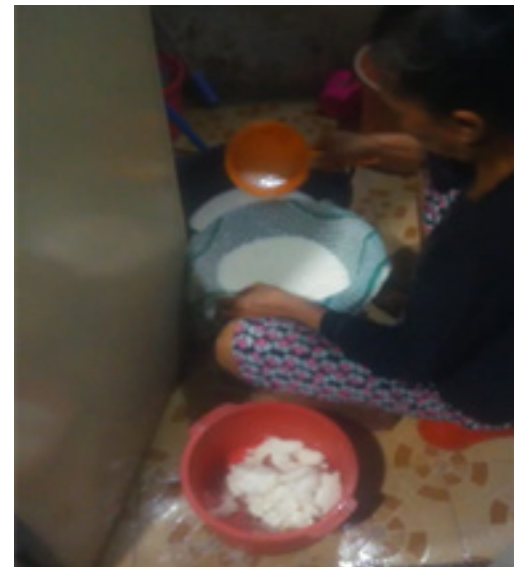

(c)

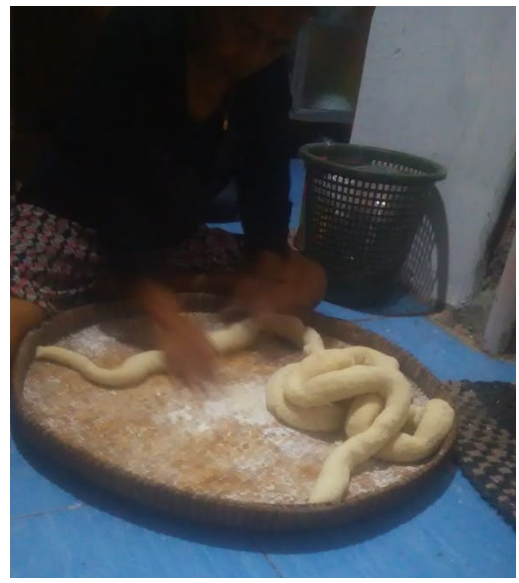

(e) kemampuan daya listrik masyarakat (Hardono 2017).

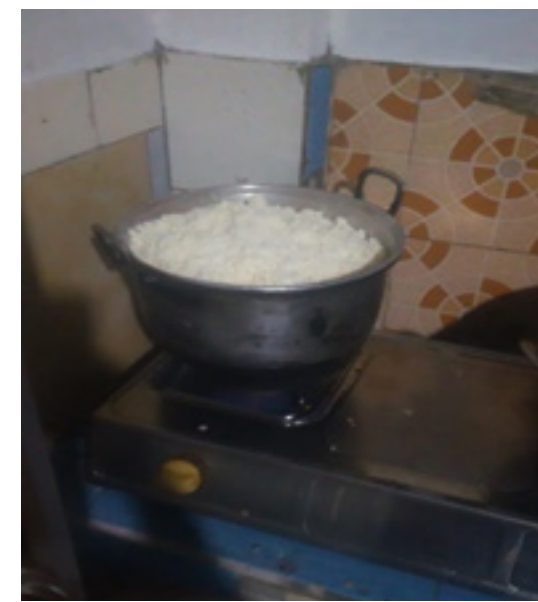

(b)

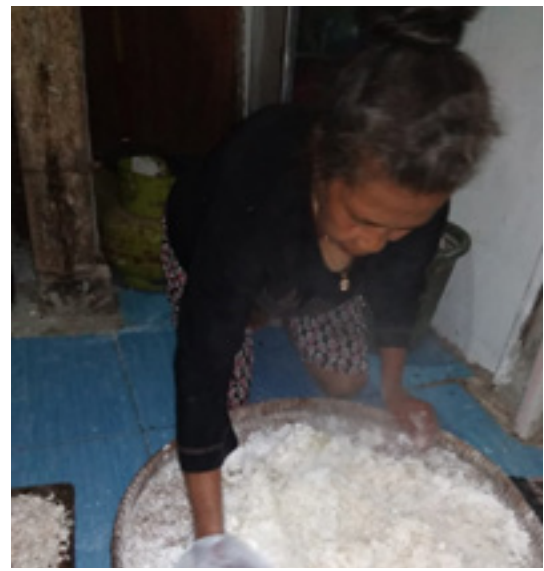

(d)

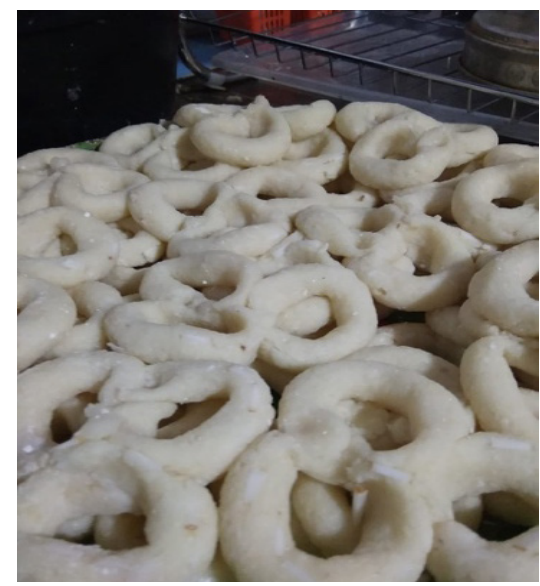

(f)

Gambar 1. Proses produksi jajanan tradisional "gebleg" (a) pemarutan singkong (b) pengukusan parutan singkong (c) pemerasan parutan singkong (d) pencampuran singkong dengan bawang dan garam (e) menguleni adonan "gebleg" dan (f) pembentukan adonan "gebleg" 
Proses perancangan mesin ini dilakukan melalui beberapa tahapan diantaranya analisis kebutuhan, perencanaan, pembuatan, dan pengujian. Analisis kebutuhan diperlukan untuk mengetahui dimensi dan kapasitas produksi dari mesin pemarut singkong yang dirancang. Penentuan dan pemilihan material juga menjadi faktor yang perlu dipertimbangkan sesuai dengan kebutuhan mesin. Material yang digunakan dalam pembuatan mesin harus kuat dan mudah diperoleh. Perancangan dan proses pembuatan bagian pemarut dari mesin pemarut dilakukan dengan memperhatikan sifat dan kekerasan umbi singkong (Mulyana, Santosa, dan Yuliati, 2016). Mesin pemarut singkong yang dirancang menggunakan sistem model cakra yang memiliki beberapa keuntungan diantaranya memerlukan penggerak yang relatif kecil serta biaya pembuatan dan perawatan yang lebih murah. Dengan menggunakan mesin pemarut sistem cakra dapat memarut dengan kapasitas produksi sekitar $60 \mathrm{~kg} / \mathrm{jam}$ (Sani, 2014). Uji kinerja mesin perlu dilakukan untuk mengetahui apakah mesin yang dibuat telah memenuhi tujuan dan kriteria yang ingin dicapai atau tidak (Thoriq dan Sutejo, 2018).

Dengan kapasitas produksi $15 \mathrm{~kg} /$ hari dan setiap kg singkong dapat menghasilkan sekitar 80 buah "gebleg" serta harga jual Rp. 800/buah, maka kira-kira pendapatan yang diperoleh Bu Murdinah adalah Rp. 64.000. Jumlah pendapatan yang diterima oleh mitra dapat meningkat melalui penerapan mesin pemarut singkong. Pemanfaatan mesin pemarut singkong dalam proses produksi "gebleg" ini diharapkan dapat meningkatkan kapasitas produksi usaha jajanan tradisional "gebleg. Hal ini dikarenakan kuantitas adonan yang dihasilkan dapat ditingkatkan kurang lebih menjadi $30 \mathrm{~kg} /$ hari, sehingga dapat menambah jumlah konsumen jajanan tradisional "gebleg". Dengan kapasitas produksi yang meningkat menjadi $30 \mathrm{~kg} /$ hari, maka pendapatan usaha jajanan tradisional meningkat menjadi $\mathrm{Rp}$. 128.000. Hal ini semakin menguatkan bahwa mesin pemarut singkong sangat diperlukan untuk menunjang keberlanjutan usaha jajanan tradisional "gebleg" di Meteseh Jayengan, Kelurahan Magelang.

\section{METODE}

Tahap awal dalam kegiatan ini adalah survei lapangan untuk memperoleh data dokumentasi dan diskusi dengan Bu Murdinah sebagai pemilik usaha jajanan tradisional "gebleg" sekaligus sebagai stakeholder. Kegiatan ini dilaksanakan untuk memperoleh data terkait prioritas permasalahan yang dapat dikembangkan lebih lanjut dari industri rumah tangga jajanan tradisional "gebleg" milik Bu Murdinah.

Hasil survei lapangan dan diskusi dengan stakeholder menunjukkan dua prioritas permasalahan mitra yang perlu segera diselesaikan yaitu:

1. Proses produksi (pemarutan singkong) dalam pembuatan jajanan tradisional "gebleg" masih dilakukan secara manual

Sebagian besar proses produksi jajanan tradisional "gebleg" di Meteseh Jayengan, Kelurahan Magelang masih dilakukan secara manual. Mulai dari proses pemarutan bahan baku, pengukusan bahan baku, pencampuran bahan baku, dan pencetakan adonan. Hal ini tentunya akan memerlukan waktu lebih lama dan tenaga yang lebih besar terutama dalam proses pemarutan singkong. Selain itu dengan menerapkan metode pemarutan konvensional menggunakan parutan sederhana, ternyata $\mathrm{Bu}$ Murdinah harus mengganti parutan setiap sepekan sekali, dikarenakan rusak. Melalui penerapan mesin sawut singkong, akan memberikan beberapa keuntungan diantaranya yaitu mempercepat waktu pemarutan singkong kurang lebih menjadi 20 menit untuk setiap $15 \mathrm{~kg}$ bahan baku singkong, kuantitas parutan singkong menjadi lebih banyak, dan jumlah produksi "gebleg", serta jumlah konsumen semakin meningkat karena kapasitas produksi yang semakin bertambah.

2. Minimnya wawasan, pengetahuan, dan pemahaman warga masyarakat tentang mesin pemarut singkong

Pengetahuan warga masyarakat Meteseh Jayengan yang masih kurang mengenai teknologi tepat guna tentang mesin sawut singkong juga menjadi permasalahan lain yang perlu diselesaikan. Pengetahuan mereka masih terbatas pada metode 
pemarutan singkong secara manual, hal ini juga dikarenakan kurangnya modal untuk pengembangan usaha. Pada umumnya metode pemarutan konvensional memerlukan waktu yang lebih lama. Melalui penerapan mesin pemarut singkong, kuantitas parutan singkong semakin banyak, sehingga dapat meningkatkan produksi jajanan tradisional "gebleg". Mesin yang dibuat memiliki bentuk yang sederhana dan kompak. Mesin pemarut singkong ini dapat dioperasikan dengan mudah dan biaya pembuatan mesin yang relatif murah. Sehingga masyarakat umum dapat mengoperasikan dengan mudah.

Tahap selanjutnya adalah identifikasi, analisis data observasi dan diskusi dari tahap pertama untuk pengembangan solusi. Pengembangan solusi yang dapat dilakukan diantaranya:

1. Meningkatnya omzet usaha jajanan "gebleg" dengan pemanfaatan mesin pemarut singkong.

Mesin pemarut singkong yang dibuat dapat meningkatkan kapasitas produksi yang secara tidak langsung meningkatkan pendapatan usaha dan meningkatkan taraf hidup masyarakat. Selain meningkatkan kapasitas produksi, dengan pemanfaatan mesin pemarut singkong dapat mendukung pengembangan usaha jajanan tradisional melalui diversifikasi produk usaha jajanan tradisional yang lain.

2. Meningkatnya wawasan, pengetahuan, dan keterampilan masyarakat melalui penyuluhan dan pelatihan pemanfaatan mesin pemarut singkong.

Penyuluhan dan pelatihan penggunaan mesin pemarut singkong diperlukan untuk memberikan wawasan, pengetahuan, dan keterampilan baru yang belum pernah diperoleh sebelumnya oleh warga masyarakat. Sehingga warga masyarakat memiliki ketrampilan terkait pengoperasian dan perawatan mesin pemarut singkong.

Tahapan program pelaksanaan Program Kemitraan Masyarakat (PKM) berdasarkan hasil survei lapangan dan diskusi dengan tokoh

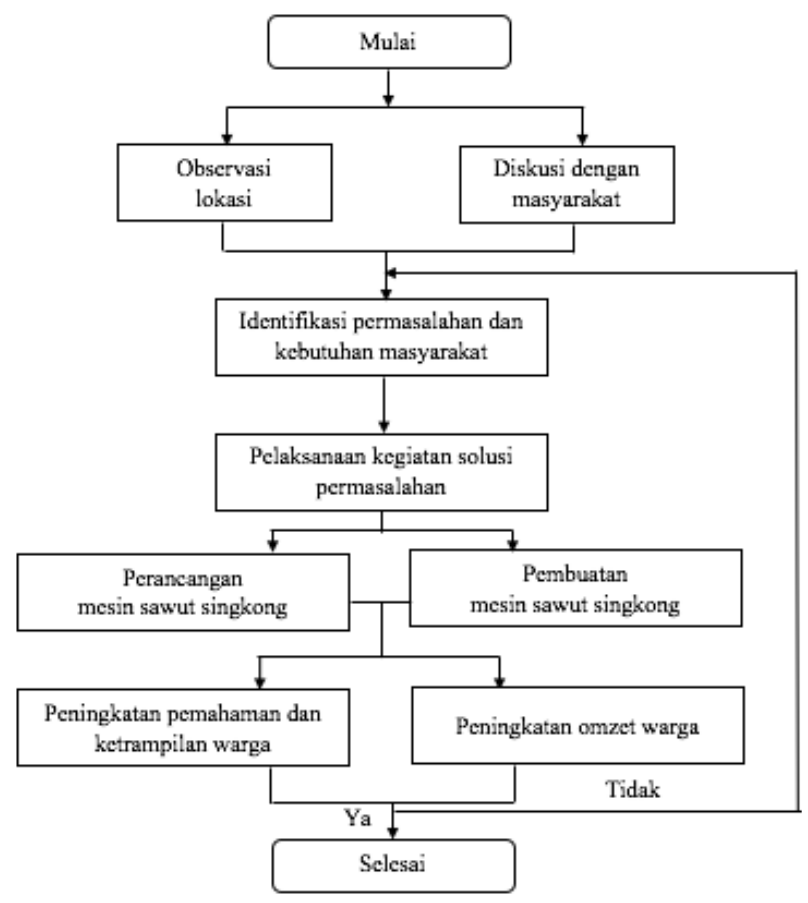

Gambar 2. Tahapan Pelaksanaan Program Kemitraan Masyarakat

masyarakat Meteseh, Jayengan, Kota Magelang ditunjukkan pada Gambar 2. Tahapan kegiatan Program Kemitraan Masyarakat (PKM) dan langkah solusi permasalahan untuk mengatasi permasalahan warga masyarakat Meteseh, Jayengan, Kota Magelang terdiri dari beberapa tahapan utama yaitu persiapan, pembuatan, pelatihan penggunaan mesin pemarut singkong, pendampingan, dan evaluasi seperti ditunjukkan pada Tabel 1 .

Tahapan teknis kegiatan ini diawali dengan melakukan koordinasi pelaksanaan kegiatan yang melibatkan mitra serta mahasiswa untuk mendapatkan persepsi yang sama. Dilanjutkan dengan persiapan alat dan bahan yang diperlukan untuk pembuatan mesin pemarut singkong. Alat yang digunakan diantaranya meliputi mesin bubut, mesin bor, trafo las, dan mesin gerinda. Mesin bubut digunakan untuk membentuk komponen mesin yang membutuhkan proses permesinan. Mesin bor digunakan untuk membuat lubang tempat memasang hopper. Trafo las digunakan untuk menyambung besi siku untuk membentuk rangka. Mesin gerinda digunakan utnuk memotong material plat alumunium, plat stainless steel, dan besi siku. Sedangkan bahan yang diperlukan meliputi plat alumunium, plat stainless steel, besi siku, 
Tabel 1. Tahapan kegiatan dan langkah solusi permasalahan

\begin{tabular}{lll}
\hline No & \multicolumn{1}{c}{ Tahapan } & \multicolumn{2}{c}{ Langkah solusi permasalahan } \\
\hline 1 & Persiapan & - Koordinasi pelaksanaan kegiatan \\
& & - Penyiapan alat dan bahan pembuatan mesin \\
& & pemarut singkong \\
\hline 2 & Pembuatan dan pelatihan penggunaan & - Proses pembuatan mesin pemarut singkong \\
& mesin pemarut singkong & Pelatihan penggunaan mesin \\
\hline 3 & Pendampingan dan evaluasi & - Pendampingan penggunaan mesin pemarut \\
& & singkong selama produksi \\
& & Evaluasi penggunaan mesin pemarut singkong \\
\hline
\end{tabular}

elektroda las, motor listrik, pulley, v-belt, bearing, cat, dan thinner. Proses pembuatan mesin pemarut singkong dibagi menjadi beberapa tahap yaitu pemotongan bahan, perakitan komponen melalui proses pengelasan dan permesinan serta pengujian. Pelatihan penggunaan mesin dilakukan untuk memastikan bahwa mitra dapat mengoperasikan mesin pemarut singkong dengan benar sesuai prosedur yang telah ditetapkan. Tahapan selanjutnya yaitu pendampingan yang dilakukan untuk memonitoring penggunaan mesin pemarut singkong oleh mitra selama produksi. Tahap terakhir yaitu melakukan evaluasi dari hasil pendampingan yang telah dilakukan, untuk mengetahui kendala yang dihadapi mitra selama penggunaan mesin pemarut singkong.

\section{HASIL DAN PEMBAHASAN}

Tim pelaksana kegiatan Program Kemitraan Masyarakat (PKM) di Meteseh, Jayengan, Magelang terdiri dari tiga orang dosen Jurusan Teknik Mesin dan dua orang mahasiswa Teknik Mesin yang mempunyai kualifikasi aktif pada kegiatan pengabdian kepada masyarakat sesuai dengan bidang keahlian masing-masing, sehingga setiap anggota tim mampu memberikan solusi terhadap permasalahan yang dihadapi oleh masyarakat. Dosen yang terlibat memiliki keahlian di di bidang desain perancangan dan manufaktur. Kegiatan ini juga akan dibantu oleh dua mahasiswa dari program studi Diploma III Teknik Mesin yaitu Rizal Andy dan Saka Sultan. Mahasiswa dalam hal ini akan membantu dalam pelaksanaan kegiatan PKM dimulai dari kegiatan survei lapangan, perancangan mesin pemarut singkong, pembuatan mesin pemarut singkong, dan pengujian mesin pemarut singkong.
Tahapan kegiatan ini diawali dengan melakukan koordinasi pelaksanaan kegiatan yang melibatkan mitra serta mahasiswa untuk mendapatkan persepsi yang sama. Dilanjutkan dengan persiapan alat dan bahan. Mesin pemarut singkong dimanufaktur melalui beberapa tahapan yaitu pembuatan desain dengan menggunakan software Solidworks, perakitan komponen-komponen mesin, dan dilanjutkan dengan uji coba. Desain menjadi dasar manufaktur mesin pemarut singkong, dengan setiap komponen dirakit menjadi satu kesatuan. Mesin yang dibuat memiliki 6 komponen utama yaitu; (a) rangka mesin, (b) motor penggerak, (c) sistem transmisi, (d) umpan (hopper), (e) cakram pemarut, dan (f) output. Rangka utama berfungsi untuk menopang bagian-bagian lain dari mesin pemarut. Rangka mesin dibuat dengan menggunakan siku 40 x $40 \mathrm{~mm}$. Motor listrik menjadi sumber tenaga penggerak awal dari mesin. Motor yang digunakan sebagai motor penggerak mesin pemarut singkong yaitu motor listrik yang memiliki daya $1 / 2 \mathrm{hp}$. Sistem transmisi yang digunakan dalam mesin pemarut singkong adalah puli, bearing, dan sabuk-v. Puli digunakan untuk mentransmisikan daya dari satu poros ke poros yang lain melalui penggunaan sabuk-v. Bearing merupakan elemen mesin yang berfungsi menumpu poros berbeban. Bearing digunakan untuk mengurangi gesekan, sehingga tidak menimbulkan aus. Sabuk-v digunakan untuk mentransmisikan daya dari poros satu ke poros yang lain dengan menggunakan puli. Pada mesin digunakan sabuk-v karena pertimbangan jarak antar puli yang tidak terlalu jauh. Bagian umpan (hopper) berfungsi sebagai saluran masuknya singkong ke cakram pemarut. Bagian ini berhubungan langsung dengan cakram 
pemarut. Cakram pemarut yang memiliki ukuran diameter $20 \mathrm{~cm}$ dari material stainless steel. Material stainless steel dipilih karena mesin yang dibuat diperuntukkan pada industri makanan, sehingga lebih aman. Material ini juga dipilih agar tidak cepat berkarat (Rijanto dan Efendi 2018). Cakram pemarut menjadi bagian yang sangat penting karena berfungsi sebagai penghancur singkong. Pemarutan dilakukan dengan menempelkan/mendorong singkong ke pisau pemarut yang sedang berputar. Output berfungsi sebagai saluran hasil parutan singkong ke wadah penampungan. Prinsip kerja mesin ini adalah di mana putaran motor listrik dilanjtukan ke puli 1 , kemudian dari puli 1 dilanjutkan ke puli 2 dengan mempergunakan sabuk-v. Pada saat motor listrik dihidupkan, motor listrik akan berputar kemudian putaran dilanjutkan oleh sabuk-v untuk memutar poros mata parut pada mesin pemarut. Hasil luaran yang diperoleh dari kegiatan Program Kemitraan Masyarakat yang dilakukan yaitu berupa mesin pemarut singkong yang tahapan pembuatannya ditunjukkan pada Gambar 2, Gambar 3 dan Gambar 4.

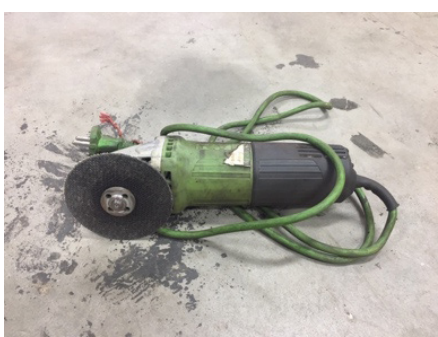

(a)

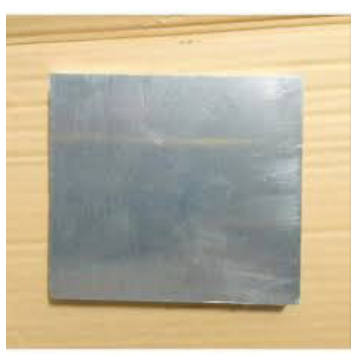

(d)

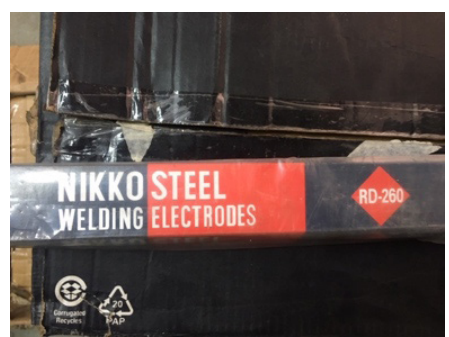

(b)

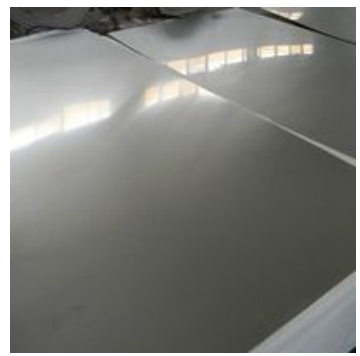

(e)

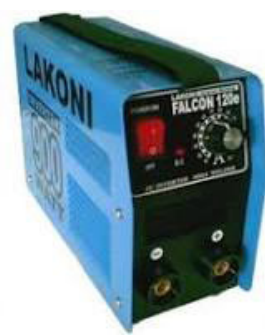

(c)

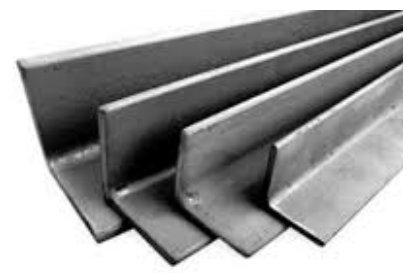

(f)

Gambar 2. Persiapan alat dan bahan (a) mesin gerinda (b) elektroda las (c) trafo las (d) plat stainless steel (pisau pemarut) (e) plat stainless steel (boks pemarut) dan (f) besi siku

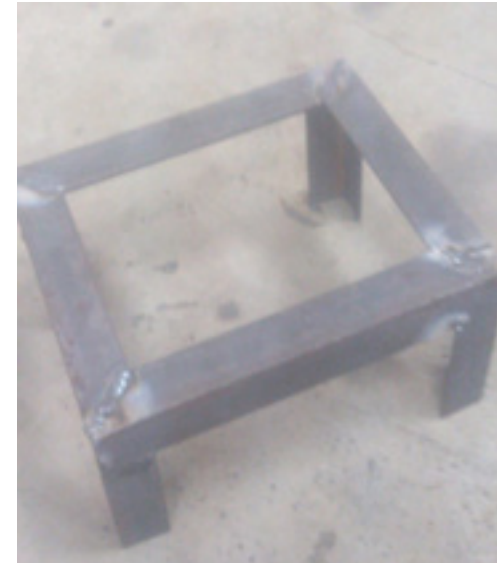

(a)

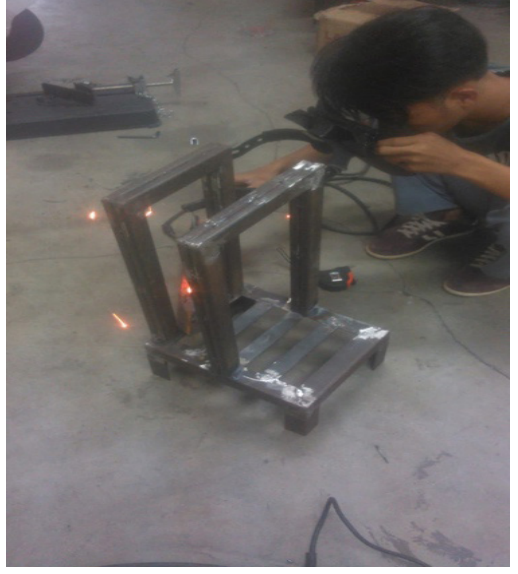

(b)

Gambar 3. Perakitan komponen (a) dudukan mesin (b) pengelasan penyangga mesin 


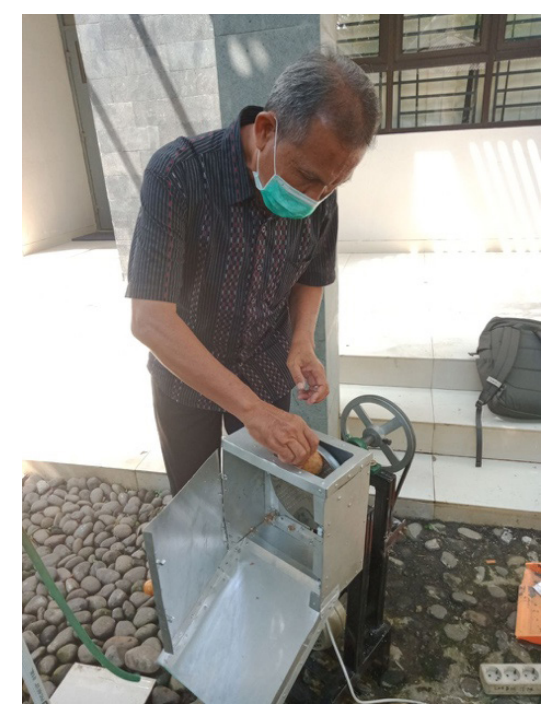

(a)

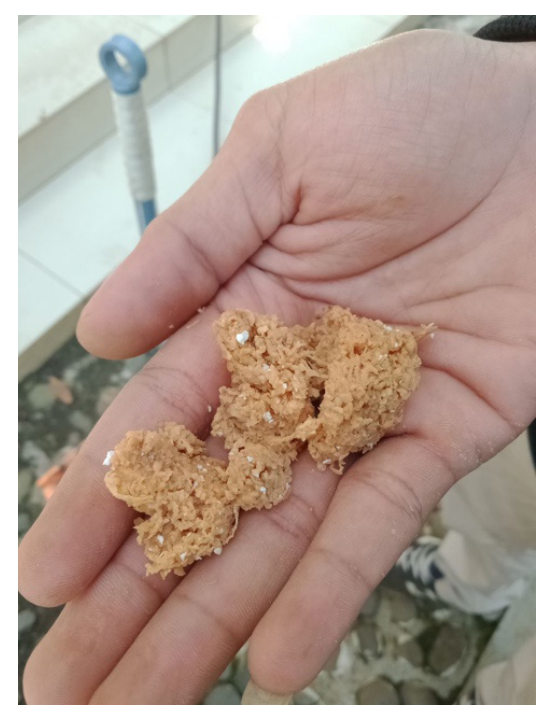

(b)

Gambar 4. (a) uji coba mesin (b) hasil parutan

Mesin pemarut singkong yang dibuat memiliki bagian boks pemarut, pisau pemarut, motor penggerak, rangka, dan sistem transmisi. Spesifikasi mesin pemarut singkong ditunjukkan pada Tabel 2.

Mesin pemarut merupakan alat yang dapat digunakan untuk mempermudah pekerjaan khususnya dalam proses pemarutan, sehingga dapat menghemat tenaga dan waktu pemarutan. Mesin pemarut singkong ini mempunyai peran penting dalam keberlangsungan proses produksi (Syakhroni dan Utomo 2019). Melalui penerapan mesin pemarut singkong, produktivitas masyarakat yang memiliki usaha makanan tradisional meningkat, baik dari segi kuantitas maupun dari segi kualitas. Selain juga dapat menurunkan jumlah orang yang harus melakukan proses pemarutan secara manual,

Tabel 2. Spesifikasi mesin pemarut singkong

\begin{tabular}{ccl}
\hline No & \multicolumn{1}{c}{ Bagian } & \multicolumn{1}{c}{ Spesifikasi } \\
\hline 1 & Boks pemarut & - Dimensi : $20 \times 40 \times 40 \mathrm{~mm}$ \\
& & - Material : stainless steel \\
\hline 2 & Pisau pemarut & - Diameter : $200 \mathrm{~mm}$ \\
& & - Material : stainless steel \\
\hline 3 & Motor penggerak & - Daya : $1 / 2 \mathrm{hp}$ \\
\hline 4 & Rangka & - Material : besi $40 \times 40 \mathrm{~mm}$ \\
\hline 5 & Sistem transmisi & - Puli 8 inch \\
& & - Puli 4 inch \\
& & - Sabuk-v A52 \\
\hline
\end{tabular}

karena yang diperlukan hanya operator mesin (Endriatno dan Kadir 2019).

Melalui penerapan mesin pemarut singkong ini, dapat mempersingkat waktu pemarutan menjadi kurang lebih 20 menit dengan kuantitas parutan yang lebih besar (30 kg/hari) yang pada awalnya hanya mampu melakukan proses pemarutan sebanyak $15 \mathrm{~kg} / \mathrm{hari}$. Dengan meningkatnya kuantitas produksi dari $15 \mathrm{~kg} /$ hari menjadi $30 \mathrm{~kg} /$ hari menghasilkan 160 buah "gebleg", pendapatan Bu Murdinah dalam penjualan "gebleg" meningkat menjadi Rp. 128.000. Selain itu dengan menggunakan mesin pemarut singkong dapat menghasilkan variasi produk jajanan tradisional lain yang lebih variatif berbasis bahan baku singkong. Tentu dengan hasil produk yang lebih variatif diharapkan dapat memperluas dan meningkatkan jumlah konsumen dari produk jajanan tradisional.

Hasil luaran lainnya yaitu meningkatnya wawasan, pengetahuan, keterampilan dan pemahaman masyarakat terkait pengoperasian mesin pemarut singkong melalui pelaksanaan kegiatan penyuluhan dan pelatihan mesin pemarut singkong. Peningkatan pengetahuan dan pemahaman warga masyarakat diketahui melalui kuesioner. Semula warga masyarakat yang mengetahui dan memahami terkait mesin pemarut singkong hanya sekitra $25 \%$ meningkat menjadi $75 \%$ setelah diadakan kegiatan penyuluhan dan pelatihan. Kegiatan penyuluhan dan pelatihan meliputi demonstrasi penggunaan 
dan perawatan mesin oleh anggota tim, uji coba oleh warga masyarakat, dan dilanjutkan dengan tanya jawab. Antusiasme warga masyarakat yang tinggi pada kegiatan penyuluhan dan pelatihan mesin pemarut singkong menunjukkan bahwa teknologi tepat guna memang sangat dibutuhkan untuk dapat mendorong meningkatnya kuantitas dan kualitas produk jajanan tradisional di wilayah Kota Magelang.

Tahap pengoperasian mesin pemarut singkong lebih rinci meliputi beberapa tahapan yaitu; (a) mempersiapkan mesin pemarut singkong; (b) mempersiapkan bahan (singkong); (c) motor listrik disambungkan ke sumber arus listrik dan diubah pada posisi ON; (d) memasukkan singkong pada hopper mesin pemarut singkong, hingga singkong dikenai gaya potong oleh cakram pemarut; (e) menampung hasil parutan singkong yang keluar pada bagian output; dan (f) mematikan mesin. Tahap uji coba dilakukan untuk memastikan bahwa setiap komponena bagian dari mesin pemarut singkong dapat berfungsi sebagaimana mestinya. Tahap uji coba dilakukan untuk mengetahui kemampuan mesin pemarut singkong dalam menghasilkan parutan.

Perawatan mesin pemarut singkong perlu dilakukan untuk memperpanjang usia dan ketahanan mesin, maka sebaiknya perawatan mesin dilakukan secara berkala. Tahap perawatan mesin meliputi; (a) pemeriksaan komponen (bearing, pulley, dan poros) dengan pemberian minyak pelumas pada komponen untuk mencegah korosi; (b) pembersihan hopper setelah setiap kali operasi untuk memperoleh hasil parutan yang lebih maksimal; dan (c) membersihkan mesin dari kotoran dan debu agar hasil parutan singkong tidak terkontaminasi debu.

Hasil pengabdian kepada masyarakat berupa mesin pemarut singkong diserahkan kepada mitra dalam hal ini Bu Murdinah di Meteseh, Jayengan, Kota Magelang pada tanggal 9 September 2020 (Gambar 4). Kegiatan dilanjutkan dengan demonstrasi penggunaan mesin sawut singkong oleh dosen dibantu dengan beberapa mahasiswa untuk memastikan bahwa mesin pemarut singkong dapat beroperasi dan mitra dapat mengoperasikan dan melakukan perawatan mesin pemarut singkong sesuai dengan prosedur yang telah ditentukan.
Bentuk partisipasi dan peran aktif warga masyarakat dalam pelaksanaan kegiatan Program Kemitraan Masyarakat (PKM) adalah ditunjukkan dengan tindakan proaktif baik secara langsung maupun tidak langsung dan memberikan saran bagi kelancaran pelaksanaan Program Kemitraan Masyarakat (PKM). Warga masyarakat Meteseh, Jayengan Kota Magelang sangat antusias dengan adanya Program Kemitraan Masyarakat (PKM). Warga masyarakat juga berharap program-program semacam ini dapat dilaksanakan secara berkelanjutan sehingga dapat meningkatkan taraf hidup warga masyarakat Meteseh Jayengan, Kecamatan Magelang Tengah, Kota Magelang.

Tahap selanjutnya terkait pelaksanaan program kemitraan masyarakat yaitu tahap evaluasi terkait penerapan mesin pemarut singkong dalam jangka panjang. Tahap ini untuk mengetahui kendala-kendala yang dihadapi mitra dalam pengoperasian mesin. Jika mitra
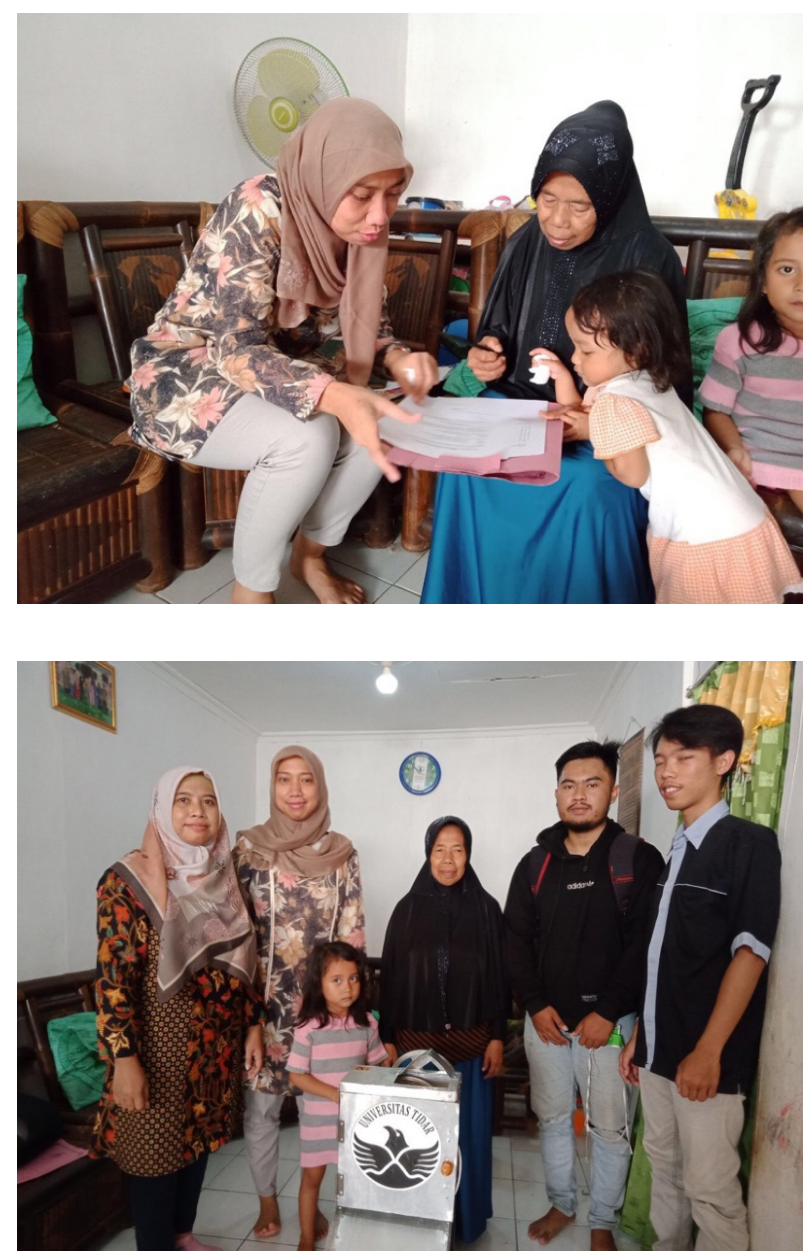

Gambar 6. Penyerahan Produk Pengabdian Kepada Masyarakat

Warta LPM, Vol. 24, No. 2, April 2021 
masih menemui kendala dalam pengoperasian mesin pemarut singkong, maka akan dilakukan pendampingan lebih lanjut oleh tim. Aspek pemasaran juga menjadi agenda lanjutan karena pemasaran jajanan "gebleg" yang dilakukan selama ini hanya melalui metode mouth to mouth dan dititipkan ke pasar tradisional. Perluasan pemasaran jajanan tradisional "gebleg" juga perlu dilakukan dengan promosi melalui media sosial (Facebook, Instagram, Twitter) dengan pembuatan kemasan yang lebih menarik sehingga dapat meningkatkan jumlah konsumen jajanan tradisional "gebleg".

\section{SIMPULAN}

Kegiatan Program Kemitraan Masyarakat (PKM) merupakan salah satu bentuk upaya penerapan teknologi tepat guna, yang dapat meningkatkan kesejahteraan masyarakat. Pada kegiatan Program Kemitraan Masyarakat (PKM) kali ini, penerapan teknologi tepat guna yang diberikan berupa mesin pemarut singkong. Mesin pemarut singkong yang dibuat memiliki kapasitas $30 \mathrm{~kg} /$ hari dengan konsumsi daya kurang lebih 20 watt. Salah satu kelebihan mesin pemarut singkong dengan penggerak menggunakan motor listrik memerlukan perawatan yang cukup mudah denga pelumasan pada komponen-komponen berputar seperti bearing. Melalui penerapan mesin pemarut singkong bagi warga Meteseh, Jayengan, Kota Magelang dapat meningkatkan kapasitas produksi hingga $30 \mathrm{~kg} / \mathrm{hari}$ dan pendapatan hingga $100 \%$. Selain itu melalui kegiatan program kemitraan masyarakat ini, keterampilan, dan pemahaman warga terkait pengoperasiam mesin pemarut singkong semakin meningkat hingga $75 \%$. Warga yang pada awalnya hanya mengenal cara pemarutan singkong secara manual, pada sekarang ini sudah dapat mengoperasikan mesin pemarut singkong.

\section{PERSANTUNAN}

Ucapan terima kasih diberikan kepada Lembaga LPPM-PMP Universitas Tidar yang telah memberikan dukungan pendanaan dan rekan-rekan Jurusan Teknik Mesin yang telah memberikan dukungan sehingga kegiatan pengabdian masyarakat ini dapat terlaksana dengan lancar. Ucapan terima kasih juga disampaikan kepada Lurah Kelurahan Magelang yang telah memberikan saran dan dukungan dalam pelaksanaan kegiatan Program Kemitraan Masyarakat (PKM) di Meteseh, Jayengan, Kota Magelang serta apresiasi juga dberikan kepada warga masyarakat Meteseh, Jayengan, Kota Magelang.

\section{REFERENSI}

Alfons, Gracia Deborah, Bambang Dwi Argo, dan Musthofa Lutfi. (2015). Rancang Bangun Mesin Pemarut Portable Menggunakan Motor Listrik AC dengan Variasi Kecepatan Putaran (RPM). Jurnal Keteknikan Pertanian Tropis dan Biosistem, 3(3), 349-355.

Aman, Wilson Palelingan, Darma Darma, Mathelda K. Roreng, dan Sardi Sardi. (2019). "Rancangan dan Kinerja Teknis Mesin Parut Singkong Tipe Silinder Bertenaga Motor Bakar.” Rekayasa, 12(1), $59-65$.

Andasuryani, Renny Eka Putri, Khandra Fahmy, Santosa, Azrifirwan, Ashadi Hasan, dan Alhapen Ruslin Chandra. (2019). Introduksi Mesin Kombinasi Pengiris dan Pemarut Ubi Kayu Untuk Usaha Olahan Makanan Ringan Skala Rumah Tangga. LOGISTA - Jurnal Ilmiah Pengabdian kepada Masyarakat, 3(2), 114-118.

Endriatno, Nanang, dan Kadir. (2019). Desain Mesin Pemarut Kelapa dan Ubi Kayu Dengan Kombinasi Rol Parut. Dinamika: Jurnal Ilmiah Teknik Mesin, 10(2),15-20.

Hardono, Joko. 2017. "Rancang Bangun Mesin Pemarut Kelapa Skala Rumah Tangga Berukuran 1 kg Per Waktu Parut 9 Menit dengan Menggunakan Motor Listrik 100 Watt." Motor Bakar: Jurnal Teknik Mesin, 1(1), 1-10. 
Ishak, Dimas, Yunita Djamalu, dan Syamsu Akuba. (2016). Perancangan Mesin Parut dan Peras Kelapa. Jurnal Teknologi Pertanian Gorontalo (JPTG), 1(2):230-50.

Mulyana, Jaka, L. M. Santosa Hadi Santosa, dan Yuliati Yuliati. (2016). Rancang Bangun Mesin Pembuatan Sari Tapioka pada Pemroses Gula Cair (Sirup Glukosa) dari Singkong (Manihot Utillisima) untuk Industri Kecil Menengah. Teknoin, 22(11):826-833.

Reniana, Darma, dan Aceng Kurniawan. (2020). Kajian Proses Pemarutan Empulur Sagu Menggunakan Alat Parut Sagu Bertenaga Manual dan Motor Bakar. Agritechnology, 2(2),71-77.

Rijanto, Achmad, dan Imaduddin Bahtiar Efendi. (2018). Rancang Bangun Mesin Parut Kelapa dengan Menggunakan Bahan Bakar Gas. Warta Industri Hasil Pertanian, 35(2), 60-67.

Sani, Almadora Anwar. (2014). Mesin Pemarut Tanaman Umbi-Umbian dengan Pemarut Model Cakra Pada Home Industry. Jurnal Austenit, 6(2), 15-20.

Siswanto, Jatmiko Edi. (2018). Analisa Produktivitas Mesin Pemarut dan Pemeras Ubi Kayu. Jurnal Civronlit Unbari, 3(1), 20-25.

Syakhroni, Akhmad, dan Sukarno Budi Utomo. (2019). Rancang Bangun Alat Pemarut dan Pemeras Santan Kelapa dengan Menggunakan 1 Motor Penggerak untuk Meningkatkan Efektivitas. Jurnal Infotekmesin, 9(2), 76-82.

Thoriq, Ahmad, dan Agus Sutejo. (2018). Modifikasi dan Uji Kinerja Mesin Pemarut Sagu Tipe Silinder. Jurnal Teknik Pertanian Lampung (Journal of Agricultural Engineering), 7(1), 35-40. 